\title{
PEMANFAATAN ICT OLEH GURU MELALUI PEMBELAJARAN MATEMATIKA BERBANTUAN MICROSOFT MATHEMATICS UNTUK MENDUKUNG IMPLEMENTASI KURIKULUM 2013
}

\author{
Rina Oktaviyanthi ${ }^{1}$, Yani Supriani ${ }^{2}$, Ria Noviana Agus $^{3}$ \\ Universitas Serang Raya \\ Jl. Raya Serang - Cilegon Km. 5 (Taman Drangong), Serang - Banten \\ E-mail: rinaokta1210@yahoo.com ${ }^{1)}$, yanisupriani92@yahoo.com ${ }^{2)}$, ria_an99@yahoo.co.id ${ }^{3)}$
}

\begin{abstract}
ABSTRAK
Dewasa ini perkembangan teknologi informasi dan komunikasi yang lebih dikenal dengan sebutan ICT telah banyak memberikan kontribusi pada kehidupan manusia termasuk bidang pendidikan. Perkembangan ICT pada sektor pendidikan memberikan peluang baru, pengaruh baik dan kontribusi positif. Kurikulum terbaru di Indonesia yaitu kurikulum 2013 yang mulai dilaksanakan pada tahun ajaran 2013-2014 memberikan warna baru dalam dunia pendidikan dimana mata pelajaran TIK/ ICT tidak lagi mata pelajaran yang berdiri sendiri melainkan diintegrasikan pada semua mata pelajaran. Terkait dengan pentingnya pemanfaatan ICT dalam pembelajaran matematika tentu perlu didukung oleh sumber daya manusia yang memiliki kompetensi pada aspek pengoperasian komputer. Untuk urgensi inilah kemudian SDM menjadi salah satu pilar utama dalam penerapan ICT di Indonesia. Tujuan utama penelitian ini adalah bagaimana pemanfaatan ICT oleh guru melalui pemmbelajaran matematika berbantuan microsoft mathematics untuk mendukung implementasi kurikuum 2013. Data yang diambil untuk melengkapi penelitian ini diambil melalui lembar observasi, angket pemahaman, dan uji Paired Sample t Test.
\end{abstract}

Kata Kunci: kurikulum 2013, microsoft mathematics, pemanfaatan ICT, pembelajaran matematika berbantuan ICT

\section{PENDAHULUAN}

Selama dekade terakhir, teknologi informasi dan komunikasi yang lebih dikenal dengan sebutan ICT (Information and Communication Technology) telah banyak memberikan banyak perubahan pada kehidupan manusia, baik dalam bekerja, berinteraksi dan memperoleh pengetahuan. Wilayah penggunaan ICT yang merambah pada bidang komputasi sosial dan pendekatan partisipasif baru berdampak pada pelayanan publik seperti pada pemerintahan, sektor kesehatan, pendidikan dan pelatihan. Perkembangan ICT pada sektor pendidikan memberikan peluang baru, pengaruh baik dan kontribusi positif. Seperti yang dilansir oleh Ala-Mutka, Punie, Redecker (2008) bahwa,

"New technologies, and especially social computing, provide new opportunities for education and training, as they enhance learning and teaching, and facilitate collaboration, innovation and creativity for individuals and organizations. The benefits of deploying social computing and ICT for learning depend on the learning approach used, emphasizing the role and the skills of the teacher and the need for supportive settings for both learners and teachers."

Integrasi ICT dalam dunia pendidikan dan aplikasinya pada kegiatan belajar mengajar di kelas bukan tanpa alasan. Dari hasil penelitian sebelumnya banyak diungkapkan mengenai hal-hal positif yang dapat diambil dari penggunaan ICT sebagai media pembelajaran dan penyampaian materi kepada peserta didik. Bingimlas (2009) dalam hasil penelitiannya menjelaskan bahwa penggunaan ICT dalam kelas sangat penting untuk memberikan kesempatan bagi peserta didik belajar mengoperasikan pembelajaran dalam era informasi dan membantu pendidik mengatasi beberapa hambatan dalam penyampaian materi. Lehtinen (2010) menyimpulkan hasil penelitiannya yaitu ICT telah memainkan peran penting baik dalam pengembangan pendekatan teoritis baru dan dalam pengujian teori lama dalam pembelajaran dan pengajaran bahwa dengan ICT menyediakan peluang bagi peserta didik belajar dengan hal baru dan melakukan kegiatan yang bermanfaat untuk mengontruksi pengetahuan.

Dalam pendidikan matematika secara global, penggunaan ICT memiliki tujuan agar peserta didik memiliki kemampuan dalam (1) critical engagement while learning Mathematics, (2) communicating, using appropriate and varied multimedia tools (emails, websites etc) while learning Mathematics, (3) efficiently using ICT in research and problem solving, dan (4) efficiently using ICT for professional development in the teaching of Mathematics (Ilomäki, 2008; Olley \& Ngamo, 2010). Adapun pandangan ICT dalam dunia pendidikan di Indonesia secara umum adalah sebagai wahana transformasi pendidikan. Lebih khususunya peran ICT yaitu sebagai (1) gudang ilmu pengetahuan, (2) alat bantu pembelajaran, (3) 
fasilitas pendidikan, dan (4) standar kompetensi (Murtiyasa, 2011).

Kurikulum terbaru di Indonesia yaitu kurikulum 2013 yang mulai dilaksanakan pada tahun ajaran 2013-2014 memberikan warna baru dalam dunia pendidikan dimana mata pelajaran TIK/ ICT tidak lagi mata pelajaran yang berdiri sendiri melainkan diintegrasikan pada semua mata pelajaran. Hal tersebut memberikan konsekuensi bagi guru sebagai fasilitator yaitu harus memiliki kemampuan dalam mengelola kelas dengan bantuan teknologi. Hal itu harus terus dilakukan agar kualitas proses dan hasil pembelajaran lebih baik, sehingga pada gilirannya dapat meningkatkan kualitas pendidikan di Indonesia. Terkait dengan pentingnya pemanfaatan ICT dalam pendidikan tentu perlu didukung oleh sumber daya manusia yang memiliki kompetensi pada aspek pengoperasian komputer. Untuk urgensi inilah kemudian SDM menjadi salah satu pilar utama dalam penerapan ICT di Indonesia. Berkembangnya ICT menjadi tantangan bagi pengajar karena pengajar memegang posisi sentral dalam proses pembelajaran di kelas. Seperti yang ditegaskan oleh Valtonen dkk. (2012) bahwa,

"Teacher holds a central position in today's society posing also demands for today's schools and teachers. Teachers need skills and pedagogical models to be able to take advantage of various information and communication technologies for supporting their students' learning at schools and also outside of schools. Teachers ought to be able to provide their students with the skills for the 21st century."

Ditambahkan pula oleh HMIe (2014) bahwa salah satu kriteria effective teacher dalam kaitannya dengan pengoperasian ICT adalah use their ICT skills to access the wealth of resources both offline and online."

Kemampuan dalam ICT inilah yang perlu diperhatikan dan ditindaklanjuti. Haddad dan Draxler (2013) menguraikan tiga dimensi pengembangan profesional pedagogis pengajar dalam mengintegrasikan teknologi pada pembelajaran, yaitu:

1. Initial preparation/training (preservice) that provides teachers with a solid foundation of knowledge; competency in teaching, classroom management, and organization skills; mastery of the subject matter they will teach; and proficiency in using a variety of educational resources, including technology.

2. Workshops, seminars, and short courses (inservice) that offer structured opportunities for acquisition of new teaching skills and subject matter knowledge, as well as skills development in the use of technology in the classroom, that are government-certified and linked to teachers' professional career development.
3. Ongoing pedagogical and technical support for teachers as they address their daily challenges and responsibilities.

Poin pertama pada tiga dimensi pengembangan profesional pedagogis pengajar yakni persiapan awal bagi pengajar, baik dalam bentuk sosialisasi atau pelatihan, di atas menjadi salah satu dasar sebagai penunjang guru dalam mendukung implementasi kurikulum 2013. SMPN 1 dan SMPN 2 Petir yang terletak di Desa Kampung Baru, Kecamatan Petir, merupakan dua sekolah menengah pertama yang terletak di Kabupaten Kota Serang. Berdasarkan wawancara yang dilakukan penulis, diketahui bahwa sebagian besar kondisi guru-guru matematika belum memiliki pemahaman yang baik mengenai ICT dalam pembelajaran matematika sehingga belum mengadaptasi peran penggunaan ICT sebagai salah satu alternatif media penyampaian materi. Untuk alasan tersebut maka guru perlu dibantu dalam membuka pengetahuan mengenai integrasi ICT di dunia pendidikan dan pemanfaatannya dalam pembelajaran, khususnya pada aspek adaptasi dan aplikasi software melalui pelatihan Microsoft Mathematics sebagai metode penyampaian materi selain metode konvensional.

Rumusan masalah yang menjadi fokus penelitian ini adalah (1) bagaimana gambaran guru sebelum dan sesudah melakukan kegiatan pelatihan Microsoft Mathematics, dan (2) bagaimana respon dan tanggapan guru dalam mengikuti kegiatan. Adapun kerangka pemecahan masalah dalam penelitian ini adalah sebagai berikut:

Tabel 1. Kerangka Pemecahan Masalah Pelatihan Microsoft Mathematics

\begin{tabular}{lll}
\hline \multicolumn{1}{c}{ Kondisi saat } & \multicolumn{1}{c}{$\begin{array}{c}\text { Perlakuan } \\
\text { yang } \\
\text { diberikan }\end{array}$} & $\begin{array}{l}\text { Kondisi yang } \\
\text { diharapkan }\end{array}$ \\
\hline $\begin{array}{l}\text {-Kurangnya } \\
\text { pengetahuan } \\
\text { dan }\end{array}$ & $\begin{array}{l}\text {-Dilakukan } \\
\text { pembekalan } \\
\text { pemahaman }\end{array}$ & $\begin{array}{l}\text {-Pengetahuan } \\
\text { dan }\end{array}$ \\
sejumai jenis- & pemahaman \\
guru & jenis media & mengenai \\
mengenai & pembelajaran & ICT \\
kegiatan & ICT & mengalami \\
inovatif yang & -Diberikan & peningkatan \\
dapat & pembekalan & memiliki \\
dilaksanakan & mengenai & kemampuan \\
di kelas & pelaksanaan & memahami \\
-Kurangnya & teknis & dan dapat \\
pemahaman & pemanfaatan & melaksanakan \\
guru dalam & ICT dalam & pembelajaran \\
penggunaan & pembelajaran & berbantuan \\
ICT dalam & & ICT \\
pembelajaran & & \\
\hline
\end{tabular}

Berdasarkan permasalahan yang diuraikan maka metode yang digunakan untuk menyelesaikan 
masalah tersebut adalah dengan pengadaan sosialisasi ICT untuk pembelajaran khususnya Matematika melalui pelatihan Microsoft Mathematics untuk mendukung implementasi kurikulum 2013. Microsoft Mathematics adalah salah satu free education software untuk mata pelajaran Matematika yang dibuat oleh Micorosft Corporation dan disebarluaskan secara gratis untuk dimanfaatkan dalam membantu siswa belajar Matematika. Rasionalisasi pemilihan Microsoft Mathematics sebagai materi pelatihan yaitu (1) Microsoft Mathematics adalah software yang dapat diunduh secara gratis, mudah dalam penginstalan, dapat digunakan pada personal computer dan windows operating system, menu yang terdapat dalam aplikasi ini sangat jelas dan mudah ditemukan; (2) Microsoft Mathematics menunjukkan langkah demi langkah jawaban dari soal-soal Kalkulus dan Aljabar sehingga membantu siswa memahami langkah pertama dalam mengerjakan soal; dan (3) Microsoft Mathematics berfungsi sebagai kalkulator grafis yang dapat membantu siswa memvisualisasikan masalah Matematika yang kompleks dan siswa dapat memulai mengembangkan solusi permasalahan melalui grafik.

Untuk menjaring data penelitian dari kegiatan sosialisasi ICT ini digunakan pendekatan kuantitatif dengan eksperimen. Eksperimen digunakan untuk menguji efektivitas dan efisiensi teknik kegiatan sosialisasi ICT. Penelitian ini menggunakan Quasi Eksperimen yaitu penelitian yang mendekati percobaan sesungguhnya dengan desain eksperimen yang digunakan adalah One-Group-Pretest-Posttest yaitu membandingkan hasil pretest dan posttest pada kelompok sampel penelitian. Rasionalisasi penggunaan metode ini karena pada situasi dan kondisi nyata tidak memungkinkan digunakannya kelas kontrol dalam penelitian.

Tabel 2. Desain Penelitian

\begin{tabular}{|l|l|l|}
\hline $\mathrm{O}_{1}$ & $\mathrm{X}$ & $\mathrm{O}_{2}$ \\
\hline
\end{tabular}

Keterangan:

$\mathrm{O}_{1} \quad$ : Pretest

$\mathrm{X}$ : Perlakuan

$\mathrm{O}_{2} \quad$ : Posttest

Adapun prosedur penelitian secara keseluruhan digambarkan pada gambar 1 berikut.

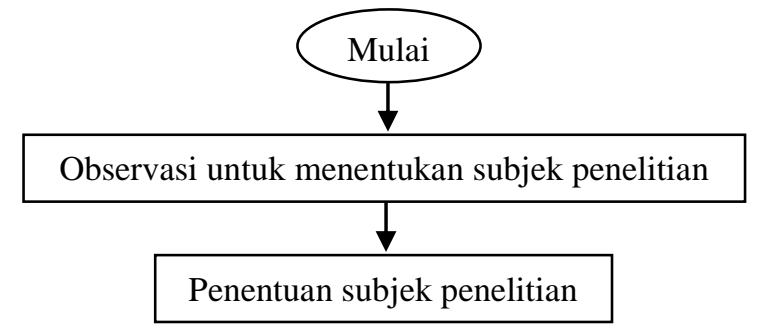

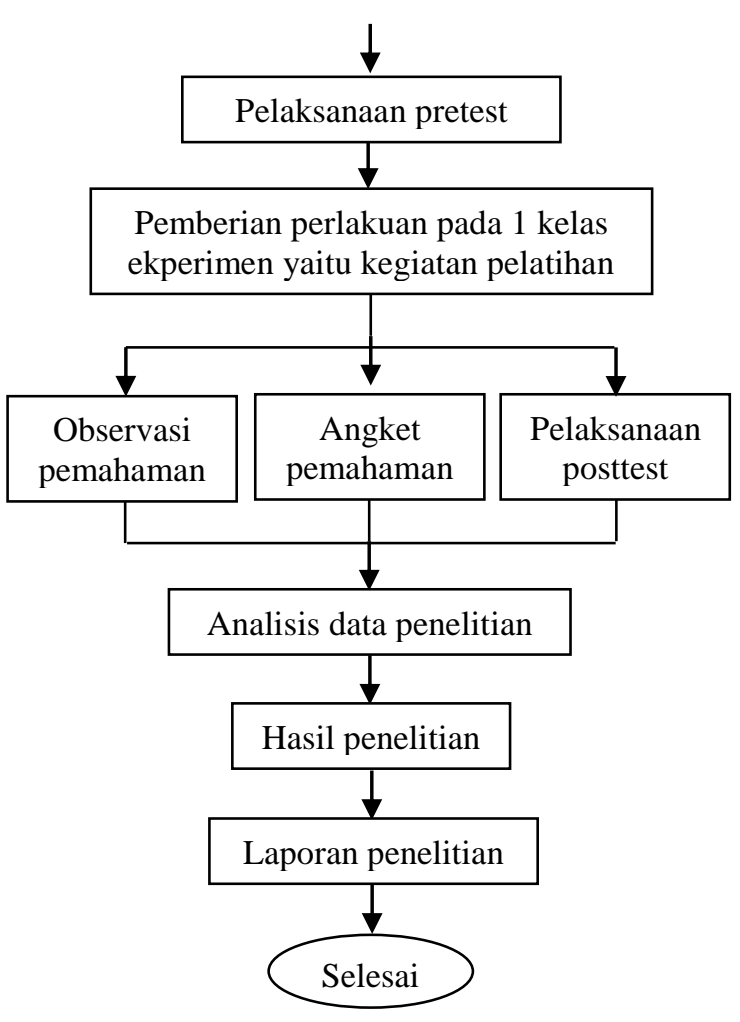

Gambar 1. Prosedur Penelitian

\section{PEMBAHASAN}

Jumlah guru matematika yang dijadikan sampel dalam penelitian ini sebanyak 15 orang dari dua sekolah yaitu SMPN 1 dan SMPN 2 Petir. Dari ke15 orang guru tersebut, mayoritas $(80 \%)$ belum pernah menggunakan ICT dalam pembelajaran matematika. Berikut keterangan sampel penelitian.

Tabel 3. Distribusi Sampel Penelitian

\begin{tabular}{ccccccc}
\hline \multicolumn{3}{c}{ Jumlah Guru } & \multicolumn{3}{c}{ Penggunaan ICT } \\
\hline Sekolah & Jenis Kelamin & Pernah & \multicolumn{3}{c}{$\begin{array}{c}\text { Belum } \\
\text { Pernah }\end{array}$} \\
\cline { 2 - 7 } & P & L & P & L & P & L \\
\hline SMPN 1 & 4 & 3 & 0 & 1 & 4 & 2 \\
\hline SMPN 2 & 5 & 3 & 1 & 1 & 4 & 2 \\
\hline Persentase & $60 \%$ & $40 \%$ & \multicolumn{2}{c}{$20 \%$} & & $80 \%$ \\
\hline
\end{tabular}

Untuk menjawab rumusan masalah dilakukan dengan pengambilan data melalui lembar observasi, pengisian angket pemahaman, dan uji-t untuk melihat keefektifan kegiatan pelatihan.

Tabel 4. Persentase Hasil Observasi Pemahaman Materi Pelatihan

\begin{tabular}{lccc}
\hline \multirow{2}{*}{ No } & \multirow{2}{*}{ Aspek yang diamati } & \multicolumn{2}{c}{ Pilihan Jawaban } \\
\cline { 3 - 4 } & Ya & Tidak \\
\hline 1 & $\begin{array}{l}\text { Apakah Bapak/ Ibu dapat } \\
\text { menjelaskan tujuan dan } \\
\text { manfaat penggunaan ICT }\end{array}$ & $86.67 \%$ & $13.33 \%$ \\
\hline
\end{tabular}




\begin{tabular}{|c|c|c|c|}
\hline & $\begin{array}{l}\text { dalam pembelajaran } \\
\text { matematika? }\end{array}$ & & \\
\hline 2 & $\begin{array}{l}\text { Apakah di sekolah } \\
\text { Bapak/ Ibu telah tersedia } \\
\text { fasilitas untuk } \\
\text { menerapkan ICT dalam } \\
\text { pembelajaran } \\
\text { matematika? }\end{array}$ & $33.33 \%$ & $66.67 \%$ \\
\hline 3 & $\begin{array}{l}\text { Apakah Bapak/ Ibu dapat } \\
\text { menjelaskan fungsi } \\
\text { Microsoft Mathematics } \\
\text { dalam pembelajaran } \\
\text { matematika? }\end{array}$ & $66.67 \%$ & $33.33 \%$ \\
\hline 4 & $\begin{array}{l}\text { Apakah Bapak/ Ibu dapat } \\
\text { menginstal software } \\
\text { Microsoft Mathematics } \\
\text { pada komputer? }\end{array}$ & $66.67 \%$ & $33.33 \%$ \\
\hline 5 & $\begin{array}{l}\text { Apakah Bapak/ Ibu dapat } \\
\text { menggunakan Microsoft } \\
\text { Mathematics dalam } \\
\text { pembelajaran } \\
\text { matematika? }\end{array}$ & $66.67 \%$ & $33.33 \%$ \\
\hline 6 & $\begin{array}{l}\text { Apakah Bapak/ Ibu dapat } \\
\text { menjelaskan tahap-tahap } \\
\text { menggunakan Microsoft } \\
\text { Mathematics? }\end{array}$ & $66.67 \%$ & $33.33 \%$ \\
\hline 7 & $\begin{array}{l}\text { Apakah Bapak/ Ibu dapat } \\
\text { membuat bahan belajar } \\
\text { matematika dengan } \\
\text { memanfaatkan Microsoft } \\
\text { Mathematics? }\end{array}$ & $66.67 \%$ & $33.33 \%$ \\
\hline 8 & $\begin{array}{l}\text { Apakah penggunaan } \\
\text { Microsoft Mathematics } \\
\text { ini dapat digunakan } \\
\text { dalam pembelajaran } \\
\text { matematika sebagai } \\
\text { wujud implementasi } \\
\text { integrasi ICT pada } \\
\text { kurikulum 2013? }\end{array}$ & $86.67 \%$ & $13.33 \%$ \\
\hline 9 & $\begin{array}{l}\text { Apakah Bapak/ Ibu } \\
\text { mengalami kesulitan } \\
\text { dalam menggunakan } \\
\text { Microsoft Mathematics? }\end{array}$ & $66.67 \%$ & $33.33 \%$ \\
\hline \multirow[t]{2}{*}{10} & $\begin{array}{l}\text { Apakah kegiatan } \\
\text { pelatihan Microsoft } \\
\text { Mathematic ini } \\
\text { memberikan manfaat } \\
\text { sebagai upaya } \\
\text { mendukung } \\
\text { pengintegrasian ICT } \\
\text { sesuai kurikulum 2013? }\end{array}$ & $86.67 \%$ & $13.33 \%$ \\
\hline & Rata-rata & $69.34 \%$ & $30.66 \%$ \\
\hline
\end{tabular}

Dari nilai rata-rata pada tabel 4 dapat dilihat secara umum pemahaman materi pelatihan guru cukup baik. Berdasarkan pengamatan penulis ada 5 orang guru yang selalu menjawab 'tidak' pada pertanyaan-pertanyaan teknis penggunaan Microsoft Mathematics. Penulis memiliki asumsi sementara bahwa faktor yang menyebabkannya adalah usia dari 5 orang guru tersebut di atas 55 tahun yang telah memiliki pengalaman mengajar dengan metode ceramah (tidak menggunakan bantuan teknologi) hampir 30 tahun. Namun untuk menjadikan hal tersebut penyebab valid, penulis perlu melakukan penyelidikan lebih lanjut dalam penelitian lain.

Tabel 5 menggambarkan persentase hasil pemahaman guru dalam menggunakan dan mengoperasikan Microsoft Mathematics melalui pelatihan yang akan diimplementasikan dalam pembelajaran.

\section{Tabel 5. Persentase Hasil Angket Pemahaman} Penggunaan Microsoft Maathematics

\begin{tabular}{|c|c|c|c|}
\hline \multirow{2}{*}{ No } & \multirow{2}{*}{ Aspek yang diamati } & \multicolumn{2}{|c|}{ Pilihan Jawaban } \\
\hline & & $\mathrm{Ya}$ & Tidak \\
\hline 1 & $\begin{array}{l}\text { Pengenalan ICT melalui } \\
\text { pelatihan membuat saya } \\
\text { mengetahui dan } \\
\text { memahami tujuan dan } \\
\text { manfaat penggunaan ICT } \\
\text { dalam pembelajaran } \\
\text { matematika }\end{array}$ & $93.33 \%$ & $6.67 \%$ \\
\hline 2 & $\begin{array}{l}\text { Melalui kegiatan } \\
\text { pelatihan saya dapat } \\
\text { mengenal jenis-jenis } \\
\text { software yang dapat } \\
\text { digunakan sebagai alat } \\
\text { bantu dalam } \\
\text { mengajarkan matematika }\end{array}$ & $86.67 \%$ & $13.33 \%$ \\
\hline 3 & $\begin{array}{l}\text { Saya dapat belajar } \\
\text { menginstal suatu } \\
\text { software matematika } \\
\text { untuk digunakan dalam } \\
\text { pembelajaran }\end{array}$ & $66.67 \%$ & $33.33 \%$ \\
\hline 4 & $\begin{array}{l}\text { Pelatihan ini membuat } \\
\text { saya lebih memahami } \\
\text { tahapan-tahapan yang } \\
\text { harus dilakukan dalam } \\
\text { merancang pembelajaran } \\
\text { matematika berbantuan } \\
\text { ICT }\end{array}$ & $86.67 \%$ & $13.33 \%$ \\
\hline 5 & $\begin{array}{l}\text { Melalui pelatihan saya } \\
\text { mengetahui penggunaan } \\
\text { Microsoft Mathematics }\end{array}$ & $100 \%$ & 0 \\
\hline 6 & $\begin{array}{l}\text { Penggunaan Microsoft } \\
\text { Mathematics dalam } \\
\text { pembelajaran } \\
\text { matematika dapat } \\
\text { membantu saya } \\
\text { mengimplementasikan } \\
\text { kurikulum } 2013\end{array}$ & $86.67 \%$ & $13.33 \%$ \\
\hline 7 & $\begin{array}{l}\text { Melalui pelatihan saya } \\
\text { dapat membuat bahan } \\
\text { ajar berbantuan ICT } \\
\text { dengan menyesuaikan } \\
\text { materi dan kurikulum }\end{array}$ & $86.67 \%$ & $13.33 \%$ \\
\hline
\end{tabular}




\begin{tabular}{|c|c|c|c|}
\hline \multirow[b]{2}{*}{8} & yang berlaku & & \\
\hline & $\begin{array}{l}\text { Dengan mengetahui } \\
\text { tahapan-tahapan } \\
\text { pembuatan bahan ajar } \\
\text { dan penggunaan } \\
\text { Microsoft Mathematics, } \\
\text { saya dapat } \\
\text { menerapkannya sendiri } \\
\text { dan mengembangkan } \\
\text { sesuai kebutuhan }\end{array}$ & $86.67 \%$ & $13.33 \%$ \\
\hline 9 & $\begin{array}{l}\text { Belajar menggunakan } \\
\text { Microsoft Mathematics } \\
\text { dengan praktik langsung } \\
\text { lebih menarik minat }\end{array}$ & $100 \%$ & 0 \\
\hline 10 & $\begin{array}{l}\text { Pelatihan penggunaan } \\
\text { ICT sebagai media } \\
\text { belajar perlu } \\
\text { diselenggarakan di } \\
\text { sekolah untuk menambah } \\
\text { pengetahuan dan } \\
\text { wawasan guru serta } \\
\text { upaya mendukung } \\
\text { implementasi kurikulum } \\
2013\end{array}$ & $100 \%$ & 0 \\
\hline & Rata-rata & $89.33 \%$ & $10.67 \%$ \\
\hline
\end{tabular}

Data pada tabel 5 menunjukkan bahwa rata-rata pemahaman guru dalam menggunakan dan mengoperasikan Microsoft Mathematics melalui pelatihan cukup besar yaitu mencapai $89.33 \%$ dan secara keseluruhan guru memberikan respon baik dan tanggapan positif dalam kegiatan ini.

Untuk melihat keefektifan kegiatan pelatihan, maka dilakukan uji Paired Sample t-test dengan menggunakan SPSS.

Tabel 6. Paired Samples Statistics

\begin{tabular}{|cl|r|r|r|c|}
\hline & Mean & N & $\begin{array}{c}\text { Std. } \\
\text { Deviation }\end{array}$ & $\begin{array}{c}\text { Std. } \\
\text { Error } \\
\text { Mean }\end{array}$ \\
\hline \multirow{2}{*}{ Pair 1 Sebelum Pelatihan } & 59,3333 & 15 & 8,83715 & 2,28174 \\
& Sesudah Pelatihan & 70,6667 & 15 & 7,98809 & 2,06252 \\
\hline
\end{tabular}

Tabel 7. Paired Samples Correlations

\begin{tabular}{|c|c|c|c|c|}
\hline & & $\mathrm{N}$ & Correlation & Sig. \\
\hline \multirow{4}{*}{ Pair 1} & Sebelum & \multirow[t]{4}{*}{15} & \multirow[t]{4}{*}{,690 } & \multirow[t]{4}{*}{,004 } \\
\hline & Pelatihan \& & & & \\
\hline & Sesudah & & & \\
\hline & Pelatihan & & & \\
\hline
\end{tabular}

Tabel 8. Paired Samples Test

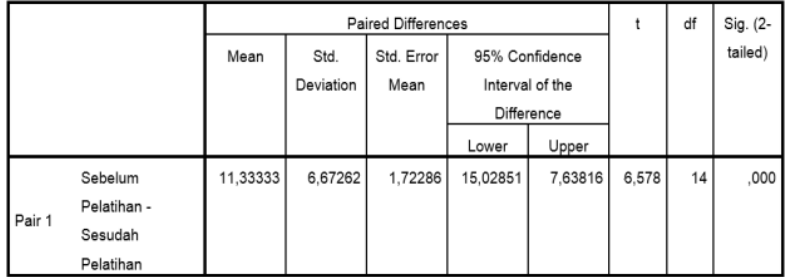

Output tabel 6 menyajikan deskripsi dari pasangan variabel yang meliputi rata-rata (mean) sebelum pelatihan 59.33 dengan standar deviasi 8.84 dan sesudah pelatihan rata-rata 70.67 dengan standar deviasi 7.98. Tabel 7 menggambarkan hasil korelasi antara kedua variabel yaitu 0.69 dengan nilai probabilitas (sig.) 0.004. Karena nilai probabilitas < 0.005 hal ini menyatakan bahwa korelasi antara sebelum pelatihan dan sesudah pelatihan berhubungan secara nyata.

Untuk mengambil keputusan maka perlu dibuat hipotesis yaitu:

$\mathrm{H} 0=$ rata-rata sebelum dan sesudah pelatihan tidak berbeda

$\mathrm{H} 1=$ rata-rata sebelum dan sesudah pelatihan berbeda

Berdasarkan perbandingan nilai probabilitas (sig.), jika probabilitas > 0.005 maka $\mathrm{H0}$ diterima dan sebaliknya jika nilai probabilitas $<0.005$ maka H0 ditolak. Dari tabel 8 terlihat bahwa t hitung 6.578 dengan nilai probabilitas 0.000 . Oleh karena probabilitas $0.000<0.005$ maka $\mathrm{H} 0$ ditolak yang berarti sebelum dan sesudah pelatihan tidak sama atau berbeda nyata.

Tanggapan dan saran guru selaku peserta pelatihan diketahui dengan pengisian angket sesudah pelatihan dilakukan.

Tabel 9. Rekapitulasi Angket Tanggapan dan Saran Peserta Pelatihan

\begin{tabular}{|c|c|c|}
\hline No & Pernyataan & Tanggapan \\
\hline 1 & $\begin{array}{l}\text { Bagaimana } \\
\text { tanggapan Bapak/ } \\
\text { Ibu mengenai } \\
\text { pelatihan ini? }\end{array}$ & $\begin{array}{l}\text { Menarik untuk } \\
\text { dilanjutkan, } \\
\text { mendukung, } \\
\text { memotivasi guru } \\
\text { menjadi profesional }\end{array}$ \\
\hline 2 & $\begin{array}{l}\text { Apakah pelatihan } \\
\text { yang kami adakan } \\
\text { bermanfaat untuk } \\
\text { Bapak/ Ibu? }\end{array}$ & $\begin{array}{l}\text { Ya, menambah } \\
\text { pengetahuan dan } \\
\text { wawasan terutama } \\
\text { mengenai media } \\
\text { belajar matematika } \\
\text { berbantuan } \\
\text { teknologi }\end{array}$ \\
\hline 3 & $\begin{array}{l}\text { Apakah pengalaman } \\
\text { dari pelatihan ini } \\
\text { dapat dipergunakan } \\
\text { oleh Bapak/ Ibu } \\
\text { dalam proses belajar } \\
\text { mengajar? }\end{array}$ & $\begin{array}{l}\text { Dapat, tetapi masih } \\
\text { perlu pendalaman } \\
\text { lebih lanjut }\end{array}$ \\
\hline 4 & $\begin{array}{l}\text { Apa terdapat } \\
\text { kesulitan yang }\end{array}$ & $\begin{array}{l}\text {-Ada, dari diri } \\
\text { sendiri karena tidak }\end{array}$ \\
\hline
\end{tabular}




\begin{tabular}{|c|c|c|}
\hline & $\begin{array}{l}\text { dihadapi Bapak/ Ibu } \\
\text { selama kegiatan } \\
\text { pelatihan ini? }\end{array}$ & $\begin{array}{l}\text { terbiasa dan } \\
\text { pengoperasian } \\
\text { computer } \\
\text {-Waktu pelatihan } \\
\text { kurang }\end{array}$ \\
\hline 5 & $\begin{array}{l}\text { Pada materi mana } \\
\text { Bapak/ Ibu merasa } \\
\text { kesulitan? }\end{array}$ & $\begin{array}{l}\text { Cara membuat } \\
\text { bahan ajar } \\
\text { berbantuan } \\
\text { teknologi yang } \\
\text { bersesuaian dengan } \\
\text { kebutuhan peserta } \\
\text { didik dan tuntutan } \\
\text { kurikulum }\end{array}$ \\
\hline 6 & $\begin{array}{l}\text { Apa saran Bapak/ } \\
\text { Ibu mengenai } \\
\text { kegiatan pelatihan } \\
\text { ini? }\end{array}$ & $\begin{array}{l}\text {-Ditindaklanjuti } \\
\text { dengan materi lain } \\
\text {-Dilakukan secara } \\
\text { berkesinambungan }\end{array}$ \\
\hline 7 & $\begin{array}{l}\text { Menurut Bapak/ Ibu } \\
\text { hal-hal apakah yang } \\
\text { perlu ditingkatkan } \\
\text { pada kegiatan } \\
\text { pelatihan ini? }\end{array}$ & $\begin{array}{l}\text {-Frekuensi } \\
\text { pelatihan } \\
\text {-Pengembangan } \\
\text { materi }\end{array}$ \\
\hline 8 & $\begin{array}{l}\text { Komentar lain yang } \\
\text { Bapak/ Ibu ingin } \\
\text { sampaikan mengenai } \\
\text { kegiatan pelatihan } \\
\text { ini? }\end{array}$ & $\begin{array}{l}\text {-Baik, } \\
\text { ditindaklanjut } \\
\text {-Waktu lebih lama } \\
\text { untuk pemula } \\
\text {-Masih ingin } \\
\text { pelatihan lagi } \\
\text {-Pelatihan bertahap }\end{array}$ \\
\hline
\end{tabular}

\section{KESIMPULAN}

Berdasarkan pembahasan lembar observasi, pengolahan angket pemahaman, dan hasil uji Paired Sample t Test dapat disimpulkan bahwa:

a. Nilai rata-rata pada tabel 4 yaitu sebesar 69.34\% menunjukkan pemahaman materi pelatihan guru secara umum cukup baik.

b. Nilai rata-rata pada tabel 5 yaitu sebesar $89.33 \%$ menunjukkan pemahaman guru dalam menggunakan dan mengoperasikan Microsoft Mathematics melalui pelatihan cukup besar.

c. Uji Paired Sample t Test menunjukkan bahwa nilai rata-rata sebelum dan sesudah pelatihan berbeda dengan perbedaan mean sebesar 11.33.

d. Secara keseluruhan guru memberikan respon baik dan tanggapan positif dalam kegiatan ini.

\section{PUSTAKA}

Ala-Mutka, K., Punie, Y., Redecker, C., 2008, ICT for Learning and Creativity, Spain: European Commission Joint Research Centre.

Bingimlas, K. A., 2009, Barriers to the Successful Integration of ICT in Teaching and Learning Environments: A Review of the Literature,
Eurasia Journal of Mathematics, Science \& Technology Education, Volume 5, Number 3, pp. 235-245.

Haddad, W. D., Draxler, A., 2013, Technologies for Education (Revised Version), Washington DC: Academy for Educational Development.

HMIe, 2014, Using ICT in Learning and Teaching (Revised Version), Scotland: HM Inspectorate of Education.

Ilomäki, L., 2008, The Effects of ICT on School: Teachers' and Students' Perspectives, Finland: University of Turku.

Lehtinen, E., 2010, Potential of Teaching and Learning Supported by ICT for The Acquisition of Deep Conceptual Knowledge and The Development of Wisdom, Finland: Centre for Learning Research, University of Turku.

Murtiyasa, Budi, 2011, ICT Dalam Sistem Pendidikan di Indonesia, Surakarta: Universitas Muhammadiyah Surakarta.

Olley, C., Ngamo, S. T., 2010, Integrating ICT in Mathematics Edcuation, Africa: Universidade Virtual Africana.

Valtonen, T., Mäkitalo-Siegl, K., Kontkanen, S., Pöntinen, S., Vartiainen, H., 2012, Facing Challenges with New Teachers' Use of ICR in Teaching and Learning, Bulletin of the IEEE Technical Committee on Learning Technology, Volume 14, Number 4, pp. 46-49. 